\title{
Large-scale habitat selection by parrots in New Caledonia
}

\author{
Andrew Legault • Vivien Chartendrault • \\ Jörn Theuerkauf $\cdot$ Sophie Rouys $\cdot$ Nicolas Barré
}

Received: 13 January 2010/Revised: 24 September 2010/Accepted: 13 October 2010/Published online: 10 November 2010

(C) The Author(s) 2010. This article is published with open access at Springerlink.com

\begin{abstract}
Habitat studies are important for conservation, particularly for parrots, as many are threatened and their ecological requirements are often poorly known. Our aim was to contribute to the conservation of parrots in New Caledonia by examining their selection of habitat at a large scale. From 2002 to 2010, we documented 1,357 encounters with New Caledonian Parakeets (Cyanoramphus saisseti), Horned Parakeets (Eunymphicus cornutus), and New Caledonian Rainbow Lorikeets (Trichoglossus
\end{abstract}

Communicated by Jon Fjeldså.

\section{A. Legault}

School of Zoology, University of Tasmania,

Private Bag 5, Hobart, Tasmania 7001, Australia

e-mail: alegault@utas.edu.au

A. Legault · J. Theuerkauf ( $\square)$

Museum and Institute of Zoology,

Polish Academy of Sciences, Wilcza 64,

00-679 Warsaw, Poland

e-mail: jtheuer@miiz.waw.pl

V. Chartendrault · N. Barré

Institut Agronomique néo-Calédonien (IAC/CIRAD),

BP 73, 98890 Païta, New Caledonia

e-mail: vivienpiou@yahoo.fr

N. Barré

e-mail: belairbarre@hotmail.fr

V. Chartendrault

Société Calédonienne d'Ornithologie,

BP 13641, 98803 Nouméa Cedex, New Caledonia

S. Rouys

Conservation Research New Caledonia,

BP 2549, 98846 Nouméa Cedex, New Caledonia

e-mail: sophierouys@lagoon.nc haematodus deplanchii) throughout mainland New Caledonia. We used GIS to infer habitat selection in relation to vegetation, forest cover, forest size, altitude, rainfall, and soil. New Caledonian Parakeets selected forested areas with oligotrophic soils, particularly those from ultramafic substrates. Horned Parakeets selected habitats with a high proportion of rainforest, as well as oligotrophic soils on metamorphic substrates, yet soil fertility was less important for them. Both parakeet species favoured large forests, and appeared to avoid areas with low forest cover. Altitude had a relatively minor influence upon habitat selection by parakeets. Rainbow Lorikeets favoured areas at low altitudes with minimal rainfall and mesotrophic soils, although they were not influenced by soil fertility to the same degree as the parakeets. We consider rainforests on oligotrophic soils at intermediate altitudes $(200-800 \mathrm{~m})$ to be most important for parrot conservation in New Caledonia, as these habitats are likely to support significant parakeet populations.

Keywords Parrot - Conservation - New Caledonia . Rainforest

Zusammenfassung Habitatstudien sind wichtig für den Artenschutz, besonders für Papageien, da viele dieser Arten bedroht und ihre ökologischen Ansprüche oft wenig bekannt sind. Unser Ziel war zum Schutz der Papageien Neukaledoniens beizutragen, indem wir deren Habitatwahl im großräumigen Maßstab untersuchten. Von 2002 bis 2010 dokumentierten wir 1357 Sichtungen von Neukaledoniensittichen (Cyanoramphus saisseti), Hornsittichen (Eunymphicus cornutus) und NeukaledonienAllfarbloris (Trichoglossus haematodus deplanchii) auf der gesamten Fläche Neukaledoniens. Mit GIS analysierten wir Habitatwahl in Bezug auf Vegetation, Waldanteil, 
Waldgröße, Höhenlage, Regenfall und Bodenart. Neukaledoniensittiche bevorzugten Wälder mit oligotrophen Böden, besonders solche auf ultrabasischen Gesteinen. Hornsittiche bevorzugten Habitate mit hohem Regenwaldanteil und mit oligotrophe Böden auf metamorphen Gesteinen, aber die Bodenfruchtbarkeit war weniger ausschlaggebend für diese Art. Beide Sitticharten bevorzugten große Waldgebiete und mieden Gebiete mit geringem Waldanteil. Die Höhenlage hatte relativ wenig Einfluss auf die Habitatwahl der Sittiche. Allfarbloris bevorzugten Gebiete niedriger Höhenlage mit minimalem Regenfall und mesotrophen Böden, aber sie waren weniger von Bodenfruchtbarkeit beeinflusst als die Sitticharten. Wir halten Regenwald auf oligotrophen Böden der mittleren Höhenlagen (200-800 m) für die wichtigsten Habitate für den Papageienschutz auf Neukaledonien, da diese Gebiete das größte Potenzial haben, um bedeutende Sittichpopulationen zu beherbergen.

\section{Introduction}

Over the past 400 years, most bird extinctions have occurred on islands, predominantly on those in the Pacific Ocean (King 1985). Nearly half (583 species) of the world's threatened birds occur on islands, and the majority of these (431 species) are found on oceanic islands far from land (BirdLife International 2008). The threat of extinction is much greater in some avian lineages than others (Bennett and Owens 1997). Parrots (Psittacidae) are particularly susceptible, with 96 of around 355 extant species (27\%) facing a high risk of extinction in the wild (BirdLife International 2009). Many parrots are ecologically specialised, and are especially vulnerable to processes that decrease niche availability, such as habitat loss (Owens and Bennett 2000). The majority inhabit tropical forests, and are at serious risk due to deforestation and forest fragmentation (Snyder et al. 2000).

The parrots of New Caledonia face three of the main factors contributing to the decline of island endemic birds, namely habitat destruction, range limitation, and introduced species (Johnson and Stattersfield 1990). Due to its relatively small size $\left(18,500 \mathrm{~km}^{2}\right)$, New Caledonia is highly susceptible to habitat loss, and only $28 \%$ of its primary vegetation remains (Brooks et al. 2002). Native dry sclerophyll forests have been severely reduced by fire, and replaced with grassland and Melaleuca quinquenervia savannah (Bouchet et al. 1995). Further reductions to dry sclerophyll forests have resulted from agricultural land clearing, and the introduction of grazing ungulates has seriously impeded forest regeneration
(Bouchet et al. 1995; de Garine-Wichatitsky et al. 2005; Spaggiari and de Garine-Wichatitsky 2006). Ultramafic outcrops support an outstanding variety of endemic plants in forest and maquis (Jaffré 1992), yet these areas are highly threatened by nickel mining and fire (McCoy et al. 1999; Morat 1993; Pascal et al. 2008). In addition, logging has removed many of the largest trees from native rainforests, and potential predators of parrots, such as introduced rats and cats, are now widespread (Rouys and Theuerkauf 2003).

The New Caledonian Parakeet (Cyanoramphus saisseti) and the Horned Parakeet (Eunymphicus cornutus) are both endemic to the main island of New Caledonia. Accounts from the late nineteenth century suggest that the two species inhabited all the forested areas at the time (Layard and Layard 1882). By the 1960s and 1970s, Horned Parakeets were relatively uncommon, yet were still known to frequent particular regions (Bregulla 1993). Since then, the number of Horned Parakeets may have fallen (Hahn 1993), though the size of their population remains unknown. Both species are currently listed as 'vulnerable' by the IUCN (2010). The New Caledonian Rainbow Lorikeet (Trichoglossus haematodus deplanchii) is an endemic subspecies, yet is considered to be of 'least concern' by the IUCN (2010). As with most parrots, poaching is a concern (Forshaw 1989), but this has not been identified as a major threat to these species (Pain et al. 2006).

New Caledonia is a global biodiversity hotspot with exceptionally high floral and faunal endemism (Myers et al. 2000); however, there is a lack of fundamental data about many of its endemic species. Habitat destruction from mining, logging, and fire has probably contributed to the decline of New Caledonia's endemic parakeets, yet it is difficult to formulate suitable conservation strategies when their ecological requirements are poorly known. In the absence of such data, conservation and management plans are appropriately based on information about habitat associations (Marsden and Fielding 1999). This has been demonstrated for several parrot species, including the endangered Ouvéa Parakeet (Eunymphicus uvaeensis) from the neighbouring island of Ouvéa, whose recovery appears to be linked to the availability of high quality habitat in forests free of poaching (Barré et al. 2010). However, detailed habitat studies remain relatively uncommon for parrots, in spite of the high proportion of endangered species in this group. The aim of our research was to contribute to the conservation of parrots inhabiting the main island of New Caledonia by providing information on their large-scale habitat preferences. We investigated the distribution of New Caledonian Parakeets, Horned Parakeets, and Rainbow Lorikeets in relation to vegetation, forest cover, forest size, altitude, rainfall, and soil. 


\section{Methods}

Study area and field work

New Caledonia (Fig. 1) is a relic of Gondwana; however, its outstanding levels of species richness and endemism are not necessarily associated with its ancient origin (Grandcolas et al. 2008). Tectonic evidence points to a period of at least partial obduction around 35 million years ago (Cluzel et al. 2001), and the island may have experienced several catastrophic periods involving mass extinctions and recent diversifications (Murienne et al. 2005). In any case, the varied environmental, topological, and geological conditions in New Caledonia are likely to

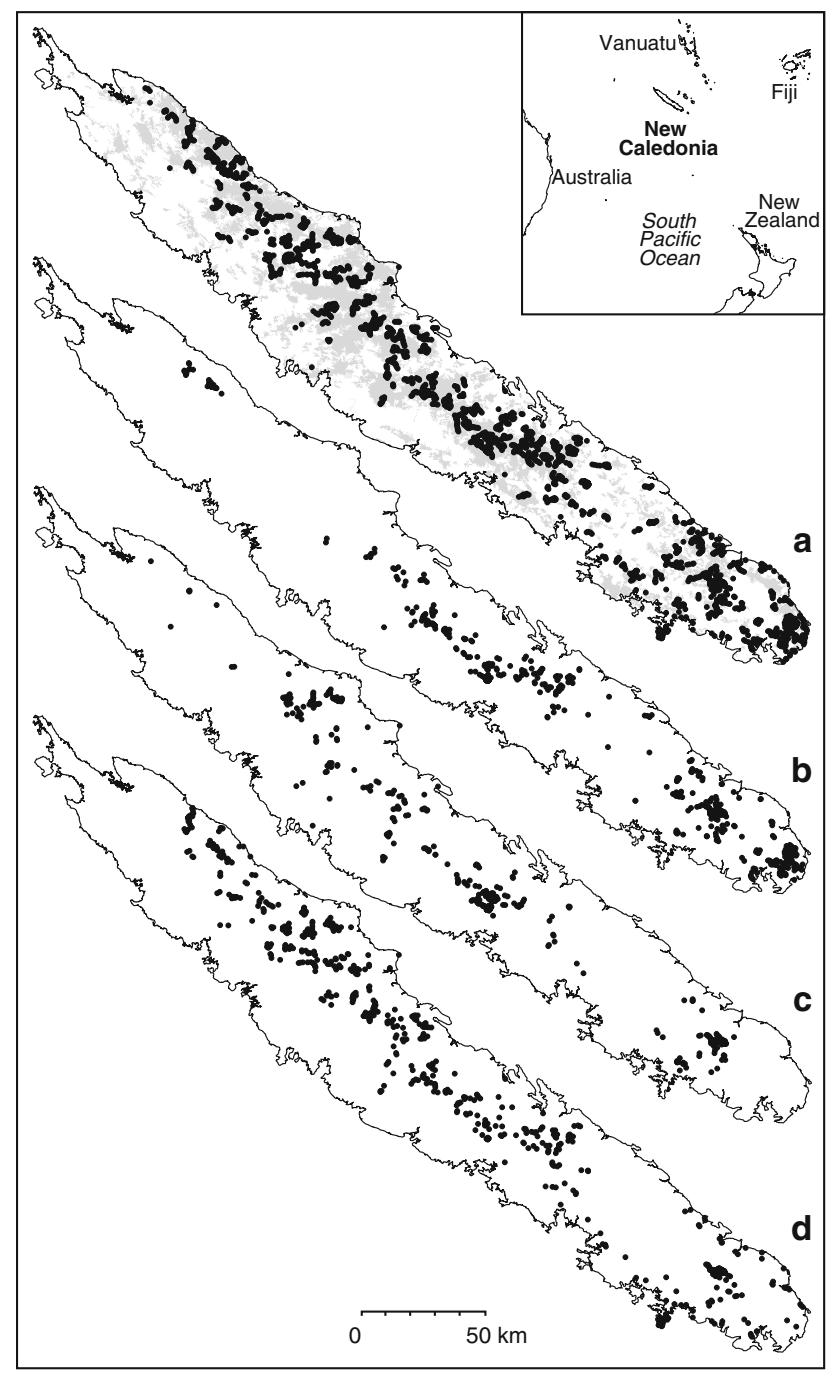

Fig. 1 Main island of New Caledonia $\left(20-22^{\circ} \mathrm{S}, 164-167^{\circ} \mathrm{E}\right)$ with a the study area (black) and forest (grey), as well as the location of encounters with b New Caledonian Parakeets (Cyanoramphus saisseti), c Horned Parakeets (Eunymphicus cornutus), and d New Caledonian Rainbow Lorikeets (Trichoglossus haematodus deplanchii) have played a large role in the evolution and distribution of its biota.

The climate of New Caledonia is classified as "tropical oceanic", and is modified by prevailing southeast trade winds. Mean annual temperatures range from 22 to $24^{\circ} \mathrm{C}$ (ORSTOM 1981); however, the lowlands can reach much higher temperatures, and frosts occasionally occur at high altitude sites. Mean annual precipitation ranges from under $1,000 \mathrm{~mm}$ on the west coast to over $4,000 \mathrm{~mm}$ along the central mountain chain (ORSTOM 1981). Peak precipitation tends to occur during the warmer months from December to April. From May to August, the weather becomes cooler, and from September to November, it is relatively dry. The highest point on the island is the summit of Mont Panié at 1,628 m.

New Caledonia has one of the most varied soil assemblages of any South Pacific island (Latham et al. 1978), and the diversity of soils is one of the main reasons for the island's unique and rich flora (Jaffré 1992). One-third of the island is characterised by the presence of ultramafic rocks and soils (Latham et al. 1978), which support a variety of sclerophyllous shrubs, collectively known as maquis (Jaffré et al. 2001). Rainforest mainly occurs along the central mountain chain of the island, though its distribution has been considerably reduced. Most of the west coast was originally dry sclerophyll forest, yet very little remains today. It has been replaced by pasture, savannah, and thickets, comprised mostly of exotic flora (Jaffré et al. 1998).

We carried out our study throughout mainland New Caledonia $\left(20-22^{\circ} \mathrm{S}, 164-167^{\circ} \mathrm{E}\right)$. Study sites covered most of the major habitat types on the island, although urban, coastal, and agricultural areas received less attention than other regions. We did not cover much of the west or northwest of New Caledonia, most of which is cleared agricultural land. These areas are unlikely to provide much suitable habitat for parakeets, although Rainbow Lorikeets occur in some regions.

From 2002 to 2010, we attempted to locate parrots throughout mainland New Caledonia using searches and point counts. Searches involved tracking parrots by their calls until we were able to see them and record their location using GPS. Point counts were carried out as part of a larger bird census (Chartendrault and Barré 2005, 2006) and involved listening for calls at selected locations from dawn to 0930 hours, and from 1530 hours to dusk. The points were spaced at intervals of $500 \mathrm{~m}$, and we listened for $15 \mathrm{~min}$ at each one. Whenever we heard parrots, we identified the species by its call, and recorded our position with a GPS receiver. All three species are mostly green, medium-sized parrots, but morphological and vocal identification was straightforward. We documented 1,357 parrot encounters across mainland New Caledonia. Of these, 
387 records were of New Caledonian Parakeets, 310 were of Horned Parakeets and 660 were of Rainbow Lorikeets.

\section{Analyses}

To compensate for the two different sampling strategies (searches and point counts), we created buffers around the location of each encounter using GIS (ArcView 3.1). For parrots detected during searches, we created a buffer with a radius of $100 \mathrm{~m}$ around the bird's location, in order to adjust for GPS error (typically around $20 \mathrm{~m}$, but always under $50 \mathrm{~m}$ ) and the imprecision of digital maps (about $50 \mathrm{~m}$ ). For parrots detected during point counts, we used a 250-m radius buffer around the researcher's location. It was necessary to use a larger buffer in this case as we did not record the distance or direction to the bird's location during point counts. Using a buffer of this size not only compensated for potential GPS and mapping errors but also covered the audible area of the listener. We are confident that most of the calls originated from within this area, due to limitations of audibility. Buffers were essential for determining the proportions of habitats surrounding each location, and they provided a more robust estimate of habitat use than could be achieved by using only the position of the parrot or observer. As we carried out searches and point counts in different locations and at different times, it is difficult to draw a direct comparison between the two datasets. Using larger buffers to compensate for the imprecision of point counts may have averaged our results slightly, but this is unlikely to have introduced bias towards any particular habitat.

Including aerial records of birds can be problematic in habitat studies, as the habitat that birds are flying over is not necessarily suitable. However, the use of buffers would have compensated for most of the spatial errors associated with the inclusion of flying birds in our study, particularly for New Caledonian Parakeets and Horned Parakeets, which typically only cover short distances in flight. We did not assess multi-scale habitat selection during this study, as we have no reason to believe that it was a factor.

Vegetation analyses were based upon an IGN (Institut Géographique National-www.ign.fr) 1:50,000 scale vector map of vegetation derived from SPOT (Système Pour l'Observation de la Terre) satellite photographs of New Caledonia. We used this map for analyses of vegetation types, forest size, forest cover (i.e. the proportion of a given area that is forested), and the mean distance to forest (i.e. the distance to the nearest vertex of a forest polygon). The precision of the map was around $50 \mathrm{~m}$, due to the map scale. We tested the accuracy of the vegetation map by comparing the vegetation types recorded during searches in the field with vegetation types taken from the map. Forest was correctly mapped in $88 \%$ of cases $(n=206)$, and other vegetation types were correctly mapped in $84 \%$ of cases $(n=49)$. We superimposed a grid over the forest map in order to calculate the distribution of different degrees of forest cover on the island. We calculated the proportion of each grid square $(500 \times 500 \mathrm{~m})$ that was covered by forest, then treated the resulting forest cover map in the same manner as the other maps.

For the vegetation analyses, we pooled the mapped vegetation types into four categories (maquis, rainforest, montane forest, and other vegetation). First, we combined dense and sparse varieties of maquis into a single habitat type, entitled 'maquis'. The vegetation map did not differentiate between forest types, so we divided the forested area into three habitats, as follows: (1) forest below $800 \mathrm{~m}$ altitude with more than 1,500 mm of annual rainfall was regarded as 'rainforest' (although this technically consists of both lowland and mid-altitude rainforest); (2) forest above $800 \mathrm{~m}$ altitude was considered 'montane forest', since the border between lowland and montane forest is between 600 and 1,000 m (Mueller-Dombois and Fosberg 1998); and (3) forest with less than $1,500 \mathrm{~mm}$ of annual rainfall was categorised as 'other vegetation', as this was mostly degraded dry forest (Bouchet et al. 1995). Mangroves, savannah, and scrub were also included in the 'other vegetation' type.

We used an IGN 1:50,000 scale digital map for altitude analyses. We assessed rainfall using a Météo France (www.meteofrance.com) 1:50,000 scale digital map of the mean annual rainfall from 1991 to 2000, which was adequate for the purposes of this study (based on around 50 weather stations). We also digitised a 1:1,000,000 scale soil map by Latham et al. (1978) to establish the distribution of soils in New Caledonia. We categorised soils as ultramafic oligotrophic (acric ferralsols), non-ultramafic oligotrophic (orthic and rhodic ferralsols), mesotrophic (acrisols, rhegosols, chromic and dystric cambisols), or eutrophic (vertisols, fluvisols, eutric cambisols), based on their value for plant productivity. Ultramafic rocks and their associated soils are common in New Caledonia. These soils have elevated levels of heavy metals and are very poor in nutrients, which hinders plant growth.

In order to calculate habitat selection, we compared the proportion of times a given habitat was used in relation to the proportion of times the habitat was expected to be used (based on its availability). We evaluated habitat use with GIS by intersecting the buffers of parrot locations with maps of habitat variables, including vegetation, forest cover, forest size, altitude, rainfall, and soil. We calculated the proportion of each category of vegetation/forest cover/ forest size/altitude/rainfall/soil per buffer, and then summed the proportions across all buffers to obtain an estimate of the total number of observations in each category. As the sum of all proportions within a single buffer was always one, the total number of observations for each species remained unchanged. To determine habitat availability in the study area, we encircled all search locations with 
500-m radius buffers, and calculated the habitat composition within the cumulative area of all buffers $\left(1,100 \mathrm{~km}^{2}\right)$. For comparison at a wider scale, we also assessed the availability of habitat on the main island of New Caledonia $\left(16,000 \mathrm{~km}^{2}\right)$. We estimated habitat selection by comparing habitat use and availability using Bonferroni 95\% confidence intervals (Byers et al. 1984; Neu et al. 1974). We use the term 'selected' to indicate when a species uses a habitat more than expected (i.e. confidence intervals above the expected proportions). A habitat is 'avoided' if a species uses it less than expected (i.e. confidence intervals below the expected proportions).

We carried out a multivariate analysis to assess the influence of habitat variables on parrot distributions. The analysis was limited to four variables (forest cover, altitude, rainfall and soil fertility), which we pooled into a small number of even classes in order to facilitate analysis. We pooled forest cover into $20 \%$ classes, altitude into $200-\mathrm{m}$ classes, rainfall into 500-mm classes, and soil into fertility classes representing oligotrophic, mesotrophic, and eutrophic conditions (around 1, 2.5 and 25 milliequivalents of exchangeable cations per $100 \mathrm{~g}$, respectively) based on Latham et al. (1978). Using GIS, we estimated the forest cover, altitude, rainfall, and soil fertility at each of the locations where we encountered parrots, and at 10,000 random points scattered throughout the study area. We calculated the number of times each species was associated with each habitat type (i.e. each combination of forest cover, altitude, rainfall, and soil fertility) and the number of times that random points were associated with each habitat type. We estimated selection values by dividing the proportion of encounters associated with a given habitat type by the proportion of random points associated with the same habitat type. To avoid problems with division by zero, we omitted several types of habitat that were not represented by random points, yet these represented less than $1 \%$ of the habitat types. Using SPSS 17 (SPSS, Chicago, IL, USA), we weighted each of the habitat types $(n=486)$ according to its frequency, as derived using random points. We generated multiple linear regression models to determine the relationship between selection values and each of the possible combinations $(n=15)$ of habitat variables in turn. To determine which of the variables most influenced habitat selection, we compared the residual sum of squares of each model using Akaike's Information Criterion (AIC), and ranked models according to their Akaike weights (Burnham and Anderson 2002).

\section{Results}

The multivariate analyses revealed that all four of the studied habitat variables (forest cover, altitude, rainfall and soil fertility) were relevant to parrots in New Caledonia, as they were all present in the highest ranking models.

\section{New Caledonian Parakeet}

Soil fertility was the highest ranking factor for New Caledonian Parakeets, with a sum of Akaike weights equal to 0.995 (Table 1). The species selected oligotrophic soils on both ultramafic substrates (acric ferralsols) and non-ultramafic substrates (orthic and rhodic ferralsols), but avoided mesotrophic and eutrophic soils (Fig. 2a). New Caledonian Parakeets used rainforest more frequently than expected, especially when compared with the overall availability of rainforest in New Caledonia (Fig. 2b). They used montane forest and maquis according to their availability, but avoided other vegetation types. Forest cover was a highly influential factor for the New Caledonian Parakeet, as indicated by its total Akaike weight of 0.833 (Table 1). The species selected areas with $80-100 \%$ forest cover and avoided areas with $0-20 \%$ forest cover (Fig. 2c). New Caledonian Parakeets also selected forest tracts over $1,000 \mathrm{~km}^{2}$ (Fig. 3a). When New Caledonian Parakeets were encountered outside forest, their average distance to forest was $63 \pm 15 \mathrm{~m}(95 \% \mathrm{CI}, n=107)$. Altitude and rainfall were less important factors, as revealed by their overall Akaike weights of 0.339 and 0.299 , respectively (Table 1). New Caledonian Parakeets selected altitudes in the range of 400-600 m, and avoided altitudes below $200 \mathrm{~m}$, which comprised nearly half of the island (Fig. 3b). The species selected areas with 2,000-2,500 $\mathrm{mm}$ of annual rainfall and avoided areas that received less than 1,500 mm (Fig. 3c).

Table 1 Multivariate linear regression models of four factors influencing habitat selection by the New Caledonian Parakeet (Cyanoramphus saisseti), ranked by Akaike weights (w)

\begin{tabular}{lllcl}
\hline Rank & Parameters in model & $w$ & $\Delta \mathrm{AIC}_{\mathrm{c}}$ & $\mathrm{AIC}_{\mathrm{c}}$ \\
\hline 1 & Soil, forest & 0.389 & 0.0 & 430.9 \\
2 & Soil, forest, altitude & 0.190 & 1.4 & 432.3 \\
3 & Soil, forest, rainfall & 0.161 & 1.8 & 432.7 \\
4 & Soil, forest, altitude, rainfall & 0.088 & 3.0 & 433.9 \\
5 & Soil & 0.078 & 3.2 & 434.1 \\
6 & Soil, altitude & 0.040 & 4.5 & 435.4 \\
7 & Soil, rainfall & 0.031 & 5.1 & 436.0 \\
8 & Soil, altitude, rainfall & 0.018 & 6.2 & 437.1 \\
9 & Forest & 0.002 & 10.5 & 441.4 \\
10 & Forest, altitude & 0.002 & 11.1 & 442.0 \\
11 & Forest, rainfall & 0.001 & 12.5 & 443.4 \\
12 & Forest, altitude, rainfall & 0.001 & 13.1 & 444.0 \\
13 & Altitude & 0.000 & 15.6 & 446.5 \\
14 & Rainfall & 0.000 & 17.2 & 448.1 \\
15 & Altitude, rainfall & 0.000 & 17.6 & 448.5 \\
\hline
\end{tabular}



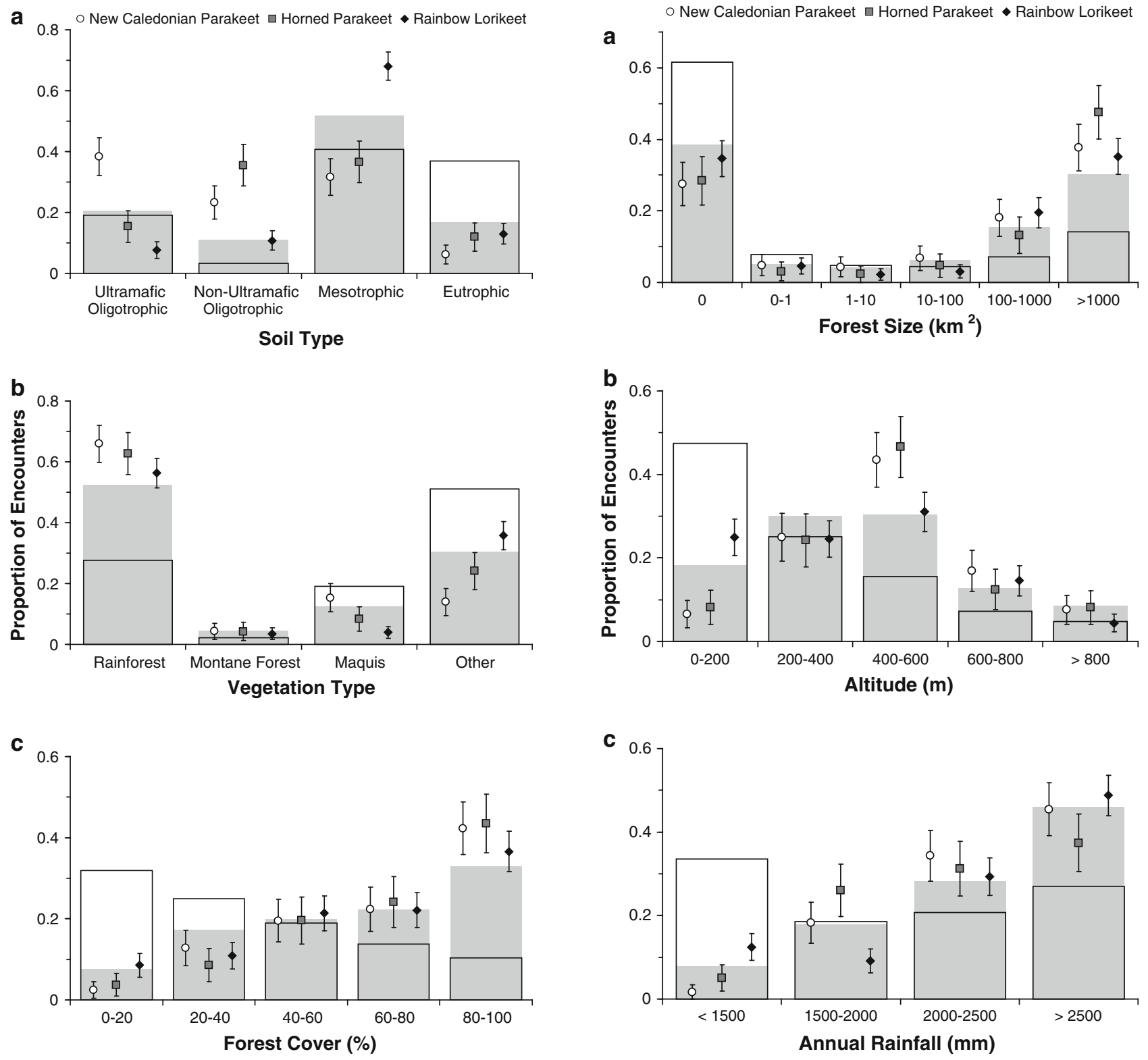

Fig. 2 Selection of a soil, $\mathbf{b}$ vegetation, and $\mathbf{c}$ forest cover by parrots in New Caledonia. The proportion of parrot encounters recorded in each habitat category is compared to the proportion of encounters expected for the study area (grey bars) and New Caledonia (transparent bars). Vertical lines represent Bonferroni 95\% confidence intervals. Confidence intervals above the expected proportions indicate selection, and confidence intervals below the expected proportions indicate avoidance

\section{Horned Parakeet}

Horned Parakeets used rainforest more frequently than expected based on its availability (Fig. 2b). They also used montane forest, but avoided maquis and other vegetation types. Forest cover proved to be the most influential factor for the Horned Parakeet, with an overall Akaike weight of 0.902 (Table 2). The species selected

Fig. 3 Selection of $\mathbf{a}$ forest size, $\mathbf{b}$ altitude, and $\mathbf{c}$ rainfall by parrots in New Caledonia. The proportion of parrot encounters recorded in each habitat category is compared to the proportion of encounters expected for the study area (grey bars) and New Caledonia (transparent bars). Vertical lines represent Bonferroni 95\% confidence intervals. Confidence intervals above the expected proportions indicate selection, and confidence intervals below the expected proportions indicate avoidance

areas with $80-100 \%$ forest cover (Fig. 2c) and forest tracts over $1,000 \mathrm{~km}^{2}$ (Fig. 3a). When outside forest, their average distance to forest was $66 \pm 13 \mathrm{~m}(95 \% \mathrm{CI}$, $n=106$ ). Rainfall was the second most influential factor for the Horned Parakeet, according to its total Akaike weight of 0.862 (Table 2). The species selected areas receiving 1,500-2,000 $\mathrm{mm}$ of rainfall per year (Fig. 3c). Horned Parakeets also selected oligotrophic soils on 
Table 2 Multivariate linear regression models of four factors influencing habitat selection by the Horned Parakeet (Eunymphicus cornutus) ranked by Akaike weights (w)

\begin{tabular}{lllll}
\hline Rank & Parameters in model & $w$ & $\Delta \mathrm{AIC}_{\mathrm{c}}$ & $\mathrm{AIC}_{\mathrm{c}}$ \\
\hline 1 & Forest, rainfall, soil & 0.287 & 0.0 & 526.9 \\
2 & Forest, rainfall & 0.261 & 0.2 & 527.1 \\
3 & Forest, rainfall, soil, altitude & 0.116 & 1.8 & 528.7 \\
4 & Forest, rainfall, altitude & 0.112 & 1.9 & 528.8 \\
5 & Forest & 0.057 & 3.2 & 530.1 \\
6 & Rainfall, soil & 0.037 & 4.1 & 531.0 \\
7 & Forest, soil & 0.036 & 4.2 & 531.1 \\
8 & Rainfall & 0.024 & 5.0 & 531.9 \\
9 & Forest, altitude & 0.021 & 5.2 & 532.1 \\
10 & Rainfall, soil, altitude & 0.015 & 5.9 & 532.8 \\
11 & Forest, soil, altitude & 0.013 & 6.1 & 533.0 \\
12 & Rainfall, altitude & 0.011 & 6.6 & 533.5 \\
13 & Soil & 0.006 & 7.7 & 534.6 \\
14 & Altitude & 0.003 & 9.3 & 536.2 \\
15 & Soil, altitude & 0.002 & 9.7 & 536.6 \\
\hline
\end{tabular}

metamorphic (non-ultramafic) volcanic rocks (orthic and rhodic ferralsols) (Fig. 2a), yet soil fertility was only moderately important, as it had an overall Akaike weight of 0.512 (Table 2). Horned Parakeets selected altitudes in the range of 400-600 $\mathrm{m}$, and avoided altitudes below $200 \mathrm{~m}$ (Fig. 3b). However, the species was least influenced by altitude, as the sum of its Akaike weights was 0.293 (Table 2).

\section{Rainbow Lorikeet}

Altitude was the highest ranking factor for Rainbow Lorikeets, with a sum of Akaike weights equal to 0.999 (Table 3). Rainfall was also influential, with an overall Akaike weight of 0.694. The species selected altitudes below $200 \mathrm{~m}$ (Fig. 3b) and areas with less than $1,500 \mathrm{~mm}$ of annual rainfall (Fig. 3c). Rainbow Lorikeets selected regions with mesotrophic soils (Fig. 2a), although soil fertility was not a particularly important factor given that its total Akaike weight was only 0.343 (Table 2). Rainbow Lorikeets were least influenced by forest cover, which had an overall Akaike weight of 0.316 . Rainbow Lorikeets were not particularly selective with respect to forest cover (Fig. 2c) or size (Fig. 3a). They used rainforest according to its availability, yet avoided maquis (Fig. 2b). Over half of mainland New Caledonia was comprised of other vegetation types, yet only the Rainbow Lorikeet selected such habitats. Their mean distance from forest was also greater than the other species, at $79 \pm 19 \mathrm{~m}(95 \% \mathrm{CI}$, $n=244)$.
Table 3 Multivariate linear regression models of four factors influencing habitat selection by the New Caledonian Rainbow Lorikeet (Trichoglossus haematodus deplanchii) ranked by Akaike weights (w)

\begin{tabular}{lllll}
\hline Rank & Parameters in model & $w$ & $\Delta \mathrm{AIC}_{\mathrm{c}}$ & $\mathrm{AIC}_{\mathrm{c}}$ \\
\hline 1 & Altitude, rainfall & 0.321 & 0.0 & 149.3 \\
2 & Altitude, rainfall, soil & 0.156 & 1.4 & 150.7 \\
3 & Altitude, rainfall, forest & 0.147 & 1.6 & 150.8 \\
4 & Altitude & 0.126 & 1.9 & 151.1 \\
5 & Altitude, soil & 0.081 & 2.8 & 152.0 \\
6 & Altitude, rainfall, soil, forest & 0.069 & 3.1 & 152.3 \\
7 & Altitude, forest & 0.062 & 3.3 & 152.6 \\
8 & Altitude, soil, forest & 0.037 & 4.3 & 153.6 \\
9 & Rainfall & 0.000 & 13.9 & 163.2 \\
10 & Forest & 0.000 & 14.5 & 163.8 \\
11 & Soil & 0.000 & 14.6 & 163.8 \\
12 & Rainfall, forest & 0.000 & 15.6 & 164.9 \\
13 & Rainfall, soil & 0.000 & 15.8 & 165.0 \\
14 & Soil, forest & 0.000 & 16.3 & 165.6 \\
15 & Rainfall, soil, forest & 0.000 & 17.5 & 166.8 \\
\hline
\end{tabular}

\section{Discussion}

Most parrots have a close association with forest, and many would probably disappear in its absence (Forshaw 1989). In our study, we found that New Caledonian Parakeets and Horned Parakeets both favoured rainforest, and were strongly influenced by forest cover. Both species selected areas with a high proportion of forest, and avoided areas with low forest cover. Parakeets were also influenced by forest size, and selected large forests. In addition, their selection of forest was probably stronger than indicated by our results since the vegetation map we used may have underestimated the presence of forest. As the map was based upon satellite photographs, it was impossible to differentiate between high and low forest, so both were simply classified as forest. Most of the mapping inaccuracies relate to the occasions where forest was incorrectly mapped as dense, low shrublands (or maquis). These errors are a consequence of using remotely sensed data; however, the accuracy of the map was sufficient for our purposes.

Rainbow Lorikeets strayed farther from forest patches than the other species, and were more likely to be found in very small forest fragments. Their substantial flight capacity and propensity to congregate into large flocks probably increases their ability to track down food resources in isolated areas (Franklin and Noske 1999; Westcott and Cockburn 1988). Rainbow Lorikeets exploit nectar from a variety of plants (Smith and Lill 2008; Waterhouse 1997), and are generally more prevalent in anthropogenic environments than in woodlands (Utschick and Brandl 1989; Legault et al., unpublished data). The species is not strictly 
dependent on forest, and will make use of most habitats as long as there are tree hollows nearby for breeding (Shukuroglou and McCarthy 2006; Waterhouse 1997). Our findings suggest that Rainbow Lorikeets cope well in a variety of habitats, including forests, scrub, and other modified landscapes. However, we may have underestimated the selection of other habitat types by Rainbow Lorikeets because we did not work in urban areas and coastal regions, where their density is highest. The fact that Rainbow Lorikeets are generalists may explain why the species has such a wide-ranging distribution in comparison with the New Caledonian Parakeet and the Horned Parakeet.

Rainforests are particularly important for parakeets in New Caledonia, as they yield a diverse and abundant source of food (authors' unpublished data) and mature rainforest trees additionally provide hollows for breeding (Robinet and Salas 1999; Theuerkauf et al. 2009). Although we assume that these are the main reasons why parakeets selected this habitat, additional research is required to determine how these and other factors might contribute to rainforest selection. At higher altitudes in New Caledonia, rainforests give way to montane forests, which are comprised of smaller trees with poorly developed trunks, and have fewer species of flowering plants (Jaffré 1995). None of the parrots in this study particularly favoured montane forests, yet the reason for this is unclear. The degree of forest cover in these regions did not appear to be a limiting factor for parrots since many of the wet, windward slopes had relatively intact forests. However, the absence of large, hollow-bearing trees suggests that there are relatively few arboreal nesting opportunities at high altitudes. Food availability may also be limited for several months of the year in montane forests, due to reductions in plant growth and photosynthetic activity associated with cooler temperatures (Nasi et al. 2002).

On the islands of Wallacea (Indonesia), Marsden and Fielding (1999) noted that lowland forests with large trees provided the most significant habitat for the most threatened parrots in the region. Unfortunately, a great deal of the lowland, level, and fertile terrain in New Caledonia has been cleared for pasture or burnt, and dry sclerophyll forests have nearly vanished as a result (Bouchet et al. 1995). Very few of the island's lowland forests remain intact, so suitable habitat is probably scarce at low altitudes. Given that parakeets are more strongly influenced by forest cover than altitude, it is likely that the avoidance of these regions by parakeets is at least partially due to forest loss. However, other factors may also be influencing selection, including the limited amount of rainfall received at low altitudes. Also, the majority of the soils in these regions are either eutrophic or mesotrophic, which were not particularly favoured by either of the parakeets in this study.
The incidence of New Caledonian Parakeets correlated well with the locations of oligotrophic soils, and the species was most prevalent in the southern part of the island, where there is a high concentration of ultramafic outcrops. An association with ultramafic rocks has previously been suggested for Horned Parakeets (Ekstrom et al. 2002); however, this relationship was stronger for the New Caledonian Parakeet. In fact, soil proved to be the most important factor driving habitat selection by New Caledonian Parakeets. While Horned Parakeets do occur on ultramafic soils, they favour forests on non-ultramafic (metamorphic or volcanic) soils. This may be the reason why Horned Parakeets were patchily distributed in the south and were more common in the central regions of the island.

Soils formed on ultramafic ranges generally have high levels of heavy metals such as nickel, and are deficient in calcium, nitrogen, phosphorus, and potassium (Lee et al. 1977). Few introduced plants are able to adapt to such edaphic conditions, and the vegetation growing upon ultramafic soils is unique. However, clearing and fires have destroyed much of the original rainforest flora, and secondary maquis dominates most of the ultramafic ranges today (Jaffré et al. 1998; McCoy et al. 1999). Our findings suggest that New Caledonian Parakeets have a certain tolerance to this vegetation type, but do not select it as previously assumed (Ekstrom et al. 2002). New Caledonian Parakeets generally avoided regions with low forest cover, which suggests that the use of maquis depends on the presence of nearby rainforests. This is particularly relevant because rainforests occupy less of the ultramafic areas than maquis (Jaffré 1992), yet seem to be far more important to this species. Other members of the Cyanoramphus genus appear to have similar habitat preferences, as they generally occur in forest and at the edges of forest (Elliott et al. 1996; Greene 1998), although some species have adapted to barren islands lacking forest (Greene 1999).

The selection of habitat by parakeets appears to be closely related to the availability of food. Preliminary research into the diet of parakeets in New Caledonia indicates that the food plants of Horned Parakeets are mainly associated with valley forest, while those of New Caledonian Parakeets are mainly associated with slope forest and forest edges (Legault et al., unpublished data). The multitude of fruits and seeds recorded by Carpenter et al. (2003) suggests that food sources are plentiful in rainforests on oligotrophic soils, despite the fact that they are nutrient deficient. Additionally, most of the trees flower and fruit during the warmest months when parakeets typically breed, and a considerable number even bear flowers and fruits in unfavourable seasons (Carpenter et al. 2003). Under ideal breeding conditions, this means that the female parakeet will rarely need to leave the nest to forage as most of the food is supplied by the male partner, or by multiple 
partners (Theuerkauf et al. 2009). Aside from any nutritional advantage this provides, reproductive success may improve because Black Rats (Rattus rattus) rarely prey upon eggs or chicks in a nest that is guarded by the female (Gula et al. 2010). However, food availability alone may not completely explain the selection of oligotrophic soils. Other soil types are equally likely to yield abundant food plants, yet parakeets did not select them. An important factor to consider is that Black Rats are scarcer and weigh less on oligotrophic soils than on other soil types in rainforest (Rouys 2008). As Black Rats might be significant predators of parakeets in New Caledonia, this may explain why parakeets are more abundant in regions with oligotrophic substrates. These habitats might be acting as a refuge, harbouring a remnant population of parakeets that may be unable to survive elsewhere. This could be the reason why parakeets no longer occupy all forested areas in New Caledonia, as was believed to be the case over a century ago (Layard and Layard 1882).

\section{Implications for conservation}

The need for habitat protection in New Caledonia currently surpasses the resources available to field biologists. Until this situation changes, the best solution for identifying critical habitat is likely to involve a combination of fieldbased data collection and GIS-based analyses. Our research indicates that forest preservation is vital to parrot conservation in New Caledonia. The deterioration or loss of forest habitat will drastically reduce the survival chances of New Caledonia's endemic parakeet species. Parakeets would benefit by protecting relatively intact rainforests on oligotrophic soils at intermediate altitudes $(200-800 \mathrm{~m})$, as these areas provide important parakeet habitat, yet are especially vulnerable to habitat loss by mining activities. Forests at higher altitudes are not the most favourable habitat for parrots in New Caledonia, nor do they provide a refuge from predatory rats (Rouys and Theuerkauf 2003), as once suspected (Nicholson and Warner 1953). However, the degradation of such environments could have a detrimental impact on forests situated at lower altitudes. Furthermore, the significance of high altitude areas may increase if New Caledonia's parrots experience elevational range shifts associated with climate change (Sekercioglu et al. 2008).

The conservation of parakeets and the conservation of other threatened avifauna can be complementary. There is considerable overlap between the habitat of New Caledonian Parakeets, Horned Parakeets, Crow Honeyeaters (Gymnomyza aubryana), and Kagus (Rhynochetos jubatus) (Hunt 1996), and suitably located reserves could benefit all these species. Only a small portion (around 4\%) of New
Caledonia is currently set aside for the conservation of fauna and flora, and many protected areas do not have strict mining bans (Jaffré et al. 1998). A network of nature reserves and wildlife corridors would therefore help to preserve critical forest habitat, and provide native fauna with an important link between isolated forest fragments.

Acknowledgments This study was part of the research project "Impact of introduced mammals and habitat loss on endemic birds of New Caledonia", done in cooperation with Province Sud (New Caledonia), which issued all permits for this study, and financed by the Loro Parque Fundación (Spain), Polish Ministry of Science and Higher Education (Grant 2P04F 001 29), Conservation des Espèces et Populations Animales (France), La Fondation Nature et Découvertes (France), Fonds für bedrohte Papageien - Zoologische Gesellschaft für Arten- und Populationsschutz (Germany), and doctoral grants from the University of Tasmania (to A. Legault) and Province Sud (to S. Rouys). Météo France kindly provided us with a map of the rainfall in New Caledonia. We thank M. Broersen, C. Chatreau, P. de Pous, D. Dingemans, S. Duijns, B. Michielsen, E. Minnema, L. Nijdam, H. Theuerkauf, J. van Dijk, M. van Opijnen and J. Wardenaar for their help during field work, and A. Richardson (University of Tasmania), D. Brightsmith, H. Theuerkauf, and anonymous reviewers for providing valuable feedback on the manuscript.

Open Access This article is distributed under the terms of the Creative Commons Attribution Noncommercial License which permits any noncommercial use, distribution, and reproduction in any medium, provided the original author(s) and source are credited.

\section{References}

Barré N, Theuerkauf J, Verfaille L, Primot P, Saoumoé M (2010) Exponential population increase in the endangered Ouvéa Parakeet (Eunymphicus uvaeensis) after community-based protection from nest poaching. J Ornithol 151:695-701

Bennett PM, Owens IPF (1997) Variation in extinction risk among birds: chance or evolutionary predisposition? Proc R Soc Lond B 264:401-408

BirdLife International (2008) Threatened birds of the world 2008. CD-ROM. BirdLife International, Cambridge, UK

BirdLife International (2009) The BirdLife checklist of the birds of the world, with conservation status and taxonomic sourcesVersion 2. http://www.birdlife.info/docs/SpcChecklist/Check list_v2_June09.zip. Accessed 27 Feb 2010

Bouchet P, Jaffré T, Veillon JM (1995) Plant extinction in New Caledonia: protection of sclerophyll forests urgently needed. Biodivers Conserv 4:415-428

Bregulla H (1993) Die Papageien Neukaledoniens. Gefiederte Welt 117:381-384

Brooks TM, Mittermeier RA, Mittermeier CG, da Fonseca GAB, Rylands AB, Konstant WR, Flick P, Pilgrim J, Oldfield S, Magin G, Hilton-Taylor C (2002) Habitat loss and extinction in the hotspots of biodiversity. Conserv Biol 16:909-923

Burnham KP, Anderson DR (2002) Model selection and multi-model inference: a practical information-theoretic approach. Springer, New York

Byers CR, Steinhorst RK, Krausman PR (1984) Clarification of a technique for analysis of utilization-availability data. J Wildl Manage 48:1050-1053

Carpenter RJ, Read J, Jaffré T (2003) Reproductive traits of tropical rain-forest trees in New Caledonia. J Trop Ecol 19:351-365 
Chartendrault V, Barré N (2005) Etude du statut et de la distribution des oiseaux menacés de la Province Nord de Nouvelle-Calédonie. Institut Agronomique néo-Calédonien, New Caledonia

Chartendrault V, Barré N (2006) Etude du statut et de la distribution des oiseaux des forêts humides de la Province Sud de NouvelleCalédonie. Institut Agronomique néo-Calédonien, New Caledonia

Cluzel D, Aitchison JC, Picard C (2001) Tectonic accretion and underplating of mafic terranes in the Late Eocene intraoceanic fore-arc of New Caledonia (Southwest Pacific): geodynamic implications. Tectonophysics 340:23-59

de Garine-Wichatitsky M, Soubeyran Y, Maillard D, Duncan P (2005) The diets of introduced rusa deer (Cervus timorensis russa) in a native sclerophyll forest and a native rainforest of New Caledonia. N Z J Zool 32:117-126

Ekstrom JMM, Jones JPG, Willis J, Tobias J, Dutson G, Barré N (2002) New information on the distribution, status and conservation of terrestrial bird species in Grande Terre, New Caledonia. Emu 102:197-207

Elliott GP, Dilks PJ, O’Donnell CFJ (1996) Nest site selection by mohua and yellow-crowned parakeets in beech forest in Fiordland, New Zealand. N Z J Zool 23:267-278

Forshaw JM (1989) Parrots of the world. Lansdowne, Melbourne

Franklin DC, Noske RA (1999) Birds and nectar in a monsoonal woodland: correlations at three spatio-temporal scales. Emu 99:15-28

Grandcolas P, Murienne J, Robillard T, Desutter-Grandcolas L, Jourdan H, Guilbert E, Deharveng L (2008) New Caledonia: a very old Darwinian island? Philos Trans R Soc Lond B 363:3309-3317

Greene TC (1998) Foraging ecology of the Red-crowned Parakeet (Cyanoramphus novaezelandiae novaezelandiae) and Yellowcrowned Parakeet (C. auriceps auriceps) on Little Barrier Island, Hauraki Gulf, New Zealand. N Z J Ecol 22:161-171

Greene TC (1999) Aspects of the ecology of Antipodes Island Parakeet (Cyanoramphus unicolor) and Reischek's Parakeet (C. novaezelandiae hochstetteri) on Antipodes Island, OctoberNovember 1995. Notornis 46:301-310

Gula R, Theuerkauf J, Rouys S, Legault AJ (2010) An audio/video surveillance system for wildlife. Eur J Wildl Res 56:803-807

Hahn P (1993) Anmerkungen zur Situation des Hornsittichs Eunymphicus cornutus auf Neukaledonien und Ouvéa. Papageien 6:189-192

Hunt GR (1996) Environmental variables associated with population patterns of the Kagu Rhynochetos jubatus of New Caledonia. Ibis 138:778-785

IUCN (2010) IUCN red list of threatened species. Version 2010.3. www.iucnredlist.org. Accessed 4 Oct 2010

Jaffré T (1992) Floristic and ecological diversity of the vegetation on ultramafic rocks in New Caledonia. In: Baker AJM, Procter J, Reeves R (eds) The vegetation of ultramafic (Serpentine) soils: proceedings of the first international conference on serpentine ecology. Intercept, Andover, UK, pp 101-107

Jaffré T (1995) Distribution and ecology of the conifers of New Caledonia. In: Enright NJ, Hill RS (eds) Ecology of the southern conifers. Melbourne University Press, Melbourne, Australia

Jaffré T, Bouchet P, Veillon JM (1998) Threatened plants of New Caledonia: is the system of protected areas adequate? Biodivers Conserv 7:109-135

Jaffré T, McCoy S, Rigault F, Navarro E (2001) A comparative study of flora and symbiotic microflora diversity in two Gymnostoma formations on ultramafic rocks in New Caledonia. S Afr J Sci 97:599-603

Johnson TH, Stattersfield AJ (1990) A global review of island endemic birds. Ibis 132:167-180
King WB (1985) Island birds: will the future repeat the past? In: Moors PJ (ed) Conservation of island birds: case studies for the management of threatened island species. ICBP Technical Publication No. 3

Latham M, Quantin P, Aubert G (1978) Étude des sols de la Nouvelle-Calédonie. ORSTOM, Paris

Layard EL, Layard ELC (1882) Notes on the avifauna of New Caledonia. Ibis 24:493-546

Lee J, Brooks RR, Reeves RD, Boswell CR, Jaffré T (1977) Plant-soil relationships in a New Caledonian serpentine flora. Plant Soil 46:675-680

Marsden SJ, Fielding A (1999) Habitat associations of parrots on the Wallacean islands of Buru, Seram and Sumba. J Biogeogr 26:439-446

McCoy S, Jaffré T, Rigault F, Ash JE (1999) Fire and succession in the ultramafic maquis of New Caledonia. J Biogeogr 26:579-594

Morat P (1993) The terrestrial biota of New Caledonia. Biodivers Lett 1:69-71

Mueller-Dombois D, Fosberg FR (1998) Vegetation of the tropical Pacific Islands. Ecological studies, vol. 132. Springer, New York

Murienne J, Grandcolas P, Piulachs MD, Bellés X, D'Haese C, Legendre F, Pellens R, Guilbert E (2005) Evolution on a shaky piece of Gondwana: is local endemism recent in New Caledonia? Cladistics 21:2-7

Myers N, Mittermeier RA, Mittermeier CG, da Fonseca GAB, Kent J (2000) Biodiversity hotspots for conservation priorities. Nature 403:853-858

Nasi R, Jaffré T, Sarrailh J-M (2002) Les forêts de montagne de la Nouvelle-Calédonie: Montane forests in New Caledonia. Bois For Trop 274:5-18

Neu CW, Byers CR, Peek JM (1974) A technique for analysis of utilization-availability data. J Wildl Manage 38:541-545

Nicholson AJ, Warner DW (1953) The rodents of New Caledonia. J Mammal 34:168-179

ORSTOM (1981) Atlas de la Nouvelle-Calédonie et Dépendances. Éditions de l'Office de la Recherche Scientifique et Technique Outre Mer (ORSTOM), Paris

Owens IPF, Bennett PM (2000) Ecological basis of extinction risk in birds: habitat loss versus human persecution and introduced predators. Proc Natl Acad Sci USA 97:12144-12148

Pain DJ, Martins TLF, Boussekey M, Diaz SH, Downs CT, Ekstrom JMM, Garnett S, Gilardi JD, McNiven D, Primot P, Rouys S, Saoumoé M, Symes CT, Tamungang SA, Theuerkauf J, Villafuerte D, Verfailles L, Widmann P, Widmann ID (2006) Impact of protection on nest take and nesting success of parrots in Africa, Asia and Australasia. Anim Conserv 9:322-330

Pascal M, Richer de Forges B, le Guyader H, Simberloff D (2008) Mining and other threats to the New Caledonian biodiversity hotspot. Conserv Biol 22:498-499

Robinet O, Salas M (1999) Reproductive biology of the endangered Ouvéa Parakeet Eunymphicus cornutus uvaeensis. Ibis 141:660-669

Rouys S (2008) Écologie des rats et leur impact sur le cagou et la perruche à front rouge en forêt humide et dans le maquis de Nouvelle-Calédonie. PhD thesis, Université de Nouvelle-Calédonie, Nouméa, New Caledonia

Rouys S, Theuerkauf J (2003) Factors determining the distribution of introduced mammals in nature reserves of the southern province, New Caledonia. Wildl Res 30:187-191

Sekercioglu CH, Schneider SH, Fay JP, Loarie SR (2008) Climate change, elevational range shifts, and bird extinctions. Conserv Biol 22:140-150

Shukuroglou P, McCarthy MA (2006) Modelling the occurrence of Rainbow Lorikeets (Trichoglossus haematodus) in Melbourne. Austral Ecol 31:240-253 
Smith J, Lill A (2008) Importance of eucalypts in exploitation of urban parks by Rainbow and Musk Lorikeets. Emu 108:187-195

Snyder N, McGowan P, Gilardi J, Grajal A (eds) (2000) Parrots. Status survey and conservation action plan 2000-2004. IUCN, Gland, Switzerland

Spaggiari J, de Garine-Wichatitsky M (2006) Home range and habitat use of introduced rusa deer (Cervus timorensis russa) in a mosaic of savannah and native sclerophyll forest of New Caledonia. N Z J Zool 33:175-183

Theuerkauf J, Rouys S, Mériot JM, Gula R, Kuehn R (2009) Cooperative breeding, mate guarding, and nest sharing in two parrot species of New Caledonia. J Ornithol 150:791-797
Utschick H, Brandl R (1989) Roosting activities of the Rainbow Lory (Trichoglossus haematodus) at Wau, Papua New Guinea. Spixinia 11:303-310

Waterhouse RD (1997) Some observations on the ecology of the Rainbow Lorikeet Trichoglossus haematodus in Oatley, South Sydney. Corella 21:17-24

Westcott DA, Cockburn A (1988) Flock size and vigilance in parrots. Aust J Zool 36:335-349 